\title{
Nutritional quality of snacks for preschoolers recommended on the internet
}

\author{
Vanessa Fernandes Amadei Santos ${ }^{1}$, Felipe Silva Neves ${ }^{1}$, Larissa Loures Mendes ${ }^{1,2}$, Mirella Lima Binoti $^{1}$
}

\begin{abstract}
Introduction: Concerns about proper nutrition in childhood have been highlighted by the media. This is accompanied by an ongoing increase in the number of Internet pages, including those on social networks, channeled toward providing health information.

Objective: To analyze the nutritional quality of snack recipes presented on web pages, aimed at preschoolers and described as healthy.

Methods: A cross-sectional study carried out in 2015. A search was made for Brazilian web pages aimed at the lay public, and that contained snacks for children between 2 and 6 years of age. The first 20 URLs located by the search engine were selected and $10 \%$ of the recipes were set apart. The snacks were checked for compliance with steps 6,7 , and 8 of the Food Guide. Subsequently, nutritional labels were made for the preparations that met the three pre-established steps.

Results: $85 \%$ of the pages were sites, $5 \%$ were blogs, and the rest were identified as sites/blogs. It was found that all were readable/comprehensible and $40 \%$ provided author identification. Of the 35 preparations initially observed, $31.4 \%$ met all three steps for healthy eating. In the qualitative analysis, seven were considered hypocaloric; only one of the snacks came close to the proposed carbohydrate content; two had excess protein. In general, the recipes had low quantities of: lipids, calcium, iron, sodium, and fiber.

Conclusion: Less than half of the addresses consulted identified the author. In addition, the recipes were predominantly misleading, as most had inadequacies in macronutrient and micronutrient content.
\end{abstract}

Keywords: child, eating habits, nutrition, internet.

\section{INTRODUCTION}

Currently, non-communicable chronic diseases exhibit alarming prevalence in a number of countries, including underdeveloped or developing countries at low/ medium socioeconomic levels, such as Brazil ${ }^{1}$.

Excess weight - including overweight and obesity stands out for showing epidemic proportions in the infantjuvenile age group, affecting children and adolescents at an early age. These changes, even if they are discrete, lead to an adverse health profile, causing premature mortality and adult morbidities ${ }^{1}$.

Among the correlated risk factors, inadequate diet - composed of ultraprocessed foods, with excess fat and high glycemic index carbohydrate contents - together with limited practice of physical activity, represent the primary contemporary triggers for weight gain ${ }^{1,2}$.

In this perspective, concerns about adequate nutrition in childhood have been highlighted by the media. ${ }^{3}$ This is accompanied by an ongoing increase in the number of Internet pages, including those on social networks, channeled toward providing health information. However, the dubious reliability exhibited by a large portion of the recommendations available on the virtual network overshadows their possible beneficial aspects ${ }^{3,4}$.

Some studies emphasize that the academic class should not ignore this reality, prompting research that leads to an evaluation of information accessed by lay peo-

\footnotetext{
1 Departamento de Nutrição, Instituto de Ciências Biológicas, Universidade Federal de Juiz de Fora - Juiz de Fora, MG, Brasil.

2 Deparamento de Nutrição, Universidade Federal de Minas Gerais (UFMG) - Belo Horizonte, MG, Brasil.

Corresponding author: Mirella Lima Binoti - E-mail: <mirella.binoti@ufjf.edu.br>. * Both authors contributed to the design and writing of this study.
}

Suggested citation: Santos VFA, Neves FS, Mendes LL, Binoti ML. Nutritional quality of snacks for preschoolers recommended on the internet. J Hum Growth Dev. 2017; 27(1): 64-70 DOI:http://dx.doi.org/10.7322/jhgd.127654

Manuscript submitted 2016, accepted for publication in Sep 2016. 
ple in digital media, since preservation of the population's health should be viewed from a variety of perspectives ${ }^{3-6}$.

Therefore, knowing the relevance of nutritional behaviors in childhood and considering the Internet's potential to disseminate misrepresented and/or misleading knowledge, the present study aims to identify the quality of recipes presented online, aimed at preschoolers and described as healthy.

\section{METHODS}

This was a cross-sectional, descriptive study carried out in 2015. First, an Internet search was conducted, using Google ${ }^{\circledR}$ (https://www.google.com.br), for Brazilian pages aimed at the lay public which contained kid's snack recipes for children from 2 to 6 years old.

It is emphasized that the term "page" refers to the URL (Uniform Resource Locators) electronic address displayed on computers, tablets, and/or smartphones.

The systematization of the data collection was defined through these procedures:

(a) Descriptors: "recipes for kids" and "heafonts and colors that do not distract the reader's attention; the illustrations are consistent with their related text; is organized in a clear and logical manner, allowing the user to navigate section to section, or from one link to another, without any conflicts ${ }^{8}$.

(b) Subsequently, a second frequency distribution was used to indicate the adequacy of the snacks in meeting the respective criteria of the "Nutrition Guide for Children under two years of age"": step 6 - "Offer the child different foods by day. A varied diet is a colorful diet"; step 7 - "Stimulate the daily consumption of fruits, greens, and other vegetables in meals"; step 8 - "Avoid sugar, coffee, canned foods, fried foods, soft drinks, candies, salty snacks, and other goodies in the early years of life. Use salt in moderation."

(c) In addition, for the preparations that simultaneously met the three pre-established steps, nutritional labels were made according to these references: RDC $359^{10}$, RDC $360^{11}$, "Brazilian Table of Food Composition"12 and "Table for Food Consumption Evaluation In Domestic Measures"13.

(d) The daily values (DV) used in preparing the labels were based on the mean recommended values for the group from 2 to 6 years of age. The requirements for macronutrients, micronutrients, and fiber (listed in Table 1) were established following the indications of the Institute of Medicine ${ }^{14}$. Consumption of $1300 \mathrm{Kcal}$ per day was considered the norm. For the snacks, $20 \%$ of the total energy was stipulated, being equivalent to $260 \mathrm{Kcal}$. The amounts of carbohydrate, protein, lipids, vitamin A, calcium, iron, and sodium in the snacks, as well as the fiber content, had to represent $20 \%$ of the recommended content ${ }^{15}$.

Table 1: Daily recommendations of macronutrients, micronutrients, and fiber for children between 2 and 6 years of age

\begin{tabular}{cccc}
\hline Macronutrients, micronutrients, and fiber & $\%$ & \multicolumn{2}{c}{ Daily Values } \\
Amount
\end{tabular}

Source: Institute of Medicine (adapted). 14

Note: Kcal - kilocalories.

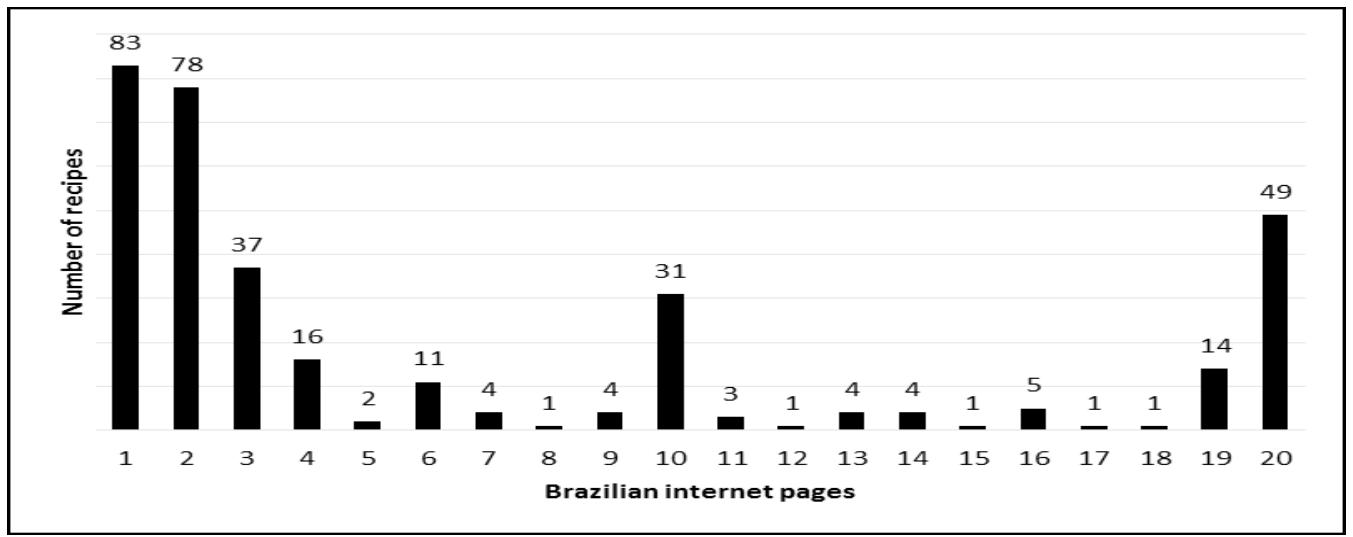

Figure 1: Number of recipes for children's snacks, recommended for those between 2 and 6 years of age, obtained from Brazilian Internet pages. 


\section{RESULTS}

In the initial stage of data collation, it was detected that the pages searched belonged to the respective categories: $85 \%(\mathrm{n}=17)$ were sites, $5 \%(\mathrm{n}=1)$ were blogs and the remaining $10 \%(\mathrm{n}=2)$ were designated as sites/blogs. Additionally, it was verified that the 20 URLs were readable/comprehensible and $40 \%(n=8)$ identified the author.

Figure 1 depicts the number of children's snacks per web address. In total, the selected pages provided 350 recipes.
Table 2 shows the frequency distribution of the 35 preparations analyzed, in terms of compliance with steps 6,7 , and 8 of the Food Guide. From this perspective, it was verified that: $22.9 \%(\mathrm{n}=8)$ did not meet any of the requirements; $28.6 \%(\mathrm{n}=10)$ met only one; $17.1 \%(\mathrm{n}=6)$ obeyed two, while $31.4 \%(\mathrm{n}=11)$ followed all three steps.

The amounts and percent adequacy of macronutrients, micronutrients, and fiber of the snacks that met the three steps for a healthy diet are itemized in Table 3. It should be noted that two preparations were excluded from this evaluation because they contained ingredients not

Table 2: Frequency of recipes for children's snacks in relation to compliance with steps 6,7 , and 8 of the Food Guide.

\begin{tabular}{cccc}
\hline Steps followed & $\mathbf{n}$ & Frequencies & \\
& 8 & \\
\hline None & 10 & 22.9 \\
1 step & 6 & 28.6 \\
2 steps & 11 & 17.1 \\
3 steps & 31.4 \\
\hline
\end{tabular}

Table 3 - Amount and percent adequacy of macronutrients, micronutrients, and fiber, of the children's snack recipes, intended for those between 2 and 6 years old, obtained from Brazilian web pages

\begin{tabular}{|c|c|c|c|c|c|c|c|c|c|}
\hline \multirow[b]{2}{*}{ Variables } & \multicolumn{8}{|c|}{ Children's snacks } & \multirow[b]{2}{*}{ Recipe IX } \\
\hline & Recipe I & Recipe II & Recipe III & Recipe IV & Recipe V & Recipe VI & Recipe VII & Recipe VIII & \\
\hline \multicolumn{10}{|l|}{ Total caloric value } \\
\hline Energy (Kcal) & 120.1 & 69.6 & 239.2 & 69.8 & 158.6 & 99.2 & 386.4 & 98.6 & 105.4 \\
\hline Adequacy (\%) & 9.2 & 5.3 & 18.4 & 5.4 & 12.2 & 7.6 & 29.7 & 7.6 & 8.1 \\
\hline \multicolumn{10}{|l|}{ Carbohydrate } \\
\hline Amount (g) & 6.9 & 10.7 & 34.2 & 12.1 & 23.6 & 15.5 & 61.0 & 13.7 & 16.2 \\
\hline Energy (Kcal) & 27.6 & 42.8 & 136.8 & 48.4 & 94.4 & 62.0 & 244.0 & 54.8 & 64.8 \\
\hline Adequacy (\%) & 3.9 & 6.0 & 19.1 & 6.8 & 13.2 & 8.7 & 34.1 & 7.7 & 9.1 \\
\hline \multicolumn{10}{|l|}{ Protein } \\
\hline Amount (g) & 11.2 & 2.2 & 18.4 & 2.2 & 8.4 & 2.1 & 21.7 & 3.3 & 9.7 \\
\hline Energy (Kcal) & 44.8 & 8.8 & 73.6 & 8.8 & 33.6 & 8.4 & 86.8 & 13.2 & 38.8 \\
\hline Adequacy (\%) & 21.5 & 4.2 & 35.4 & 4.2 & 16.1 & 4.0 & 41.7 & 6.3 & 18.6 \\
\hline \multicolumn{10}{|l|}{ Lipids } \\
\hline Amount (g) & 5.3 & 2.0 & 3.2 & 1.4 & 3.4 & 3.2 & 6.2 & 3.4 & 0.2 \\
\hline Energy (Kcal) & 47.7 & 18.0 & 28.8 & 12.6 & 30.6 & 28.8 & 55.8 & 30.6 & 1.8 \\
\hline Adequacy (\%) & 10.5 & 4.0 & 6.3 & 2.8 & 6.7 & 6.3 & 12.3 & 6.7 & 0.4 \\
\hline \multicolumn{10}{|l|}{ Vitamin A } \\
\hline Amount $(\mu \mathrm{g})$ & 315.4 & 1.0 & 237.6 & 103.0 & 9.5 & 127.9 & 108.3 & 64.7 & 2.5 \\
\hline Adequacy (\%) & 90.1 & 0.3 & 67.9 & 29.4 & 2.7 & 36.5 & 30.9 & 18.5 & 0.7 \\
\hline \multicolumn{10}{|l|}{ Calcium } \\
\hline Amount (mg) & 29.8 & 78.0 & 149.6 & 72.7 & 144.3 & 38.0 & 154.4 & 36.1 & 5.1 \\
\hline Adequacy (\%) & 4.6 & 12.0 & 23.0 & 11.2 & 22.2 & 5.8 & 23.7 & 5.5 & 0.8 \\
\hline \multicolumn{10}{|l|}{ Iron } \\
\hline Amount (mg) & 2.0 & 0.4 & 2.3 & 0.4 & 1.1 & 0.9 & 3.2 & 0.5 & 0.3 \\
\hline Adequacy (\%) & 14.9 & 3.0 & 17.0 & 3.0 & 8.1 & 6.7 & 23.7 & 3.7 & 2.2 \\
\hline \multicolumn{10}{|l|}{ Sodium } \\
\hline Amount (g) & 0.006 & 0.03 & 0.3 & 0.02 & 0.06 & 0.04 & 0.17 & 0.04 & 0 \\
\hline Adequacy (\%) & 0.54 & 2.7 & 27.3 & 1.8 & 5.4 & 3.6 & 15.4 & 3.6 & 0 \\
\hline \multicolumn{10}{|l|}{ Fiber } \\
\hline Amount (g) & 1.4 & 0.7 & 2.4 & 1.0 & 1.0 & 0.4 & 3.1 & 0.2 & 1.1 \\
\hline Adequacy (\%) & 6.4 & 3.2 & 10.9 & 4.5 & 4.5 & 1.8 & 14.1 & 0.9 & 5.0 \\
\hline
\end{tabular}

Note: Kcal - kilocalories.

found in the food composition tables. Thus, the sample submitted to nutritional calculations was composed of nine recipes.

Preparations I, II, IV, V, VI, VIII, and IX were considered hypocaloric in relation to the DV. Only snack III came close to the proposed carbohydrate content $(34.2 \mathrm{~g}$,
$19.1 \%$ adequacy). Snacks III and VII presented excess protein $(18.4 \mathrm{~g}, 35.4 \%$ adequacy; $21.7 \mathrm{~g}, 41.7 \%$ adequacy, respectively); I, III, VI, and VII had high levels of vitamin A.

In general, the recipes had low amounts of: lipids, calcium, iron, sodium, and fiber. However, preparation III showed a high sodium content $(0.3 \mathrm{~g}, 27.3 \%$ adequacy $)$. 


\section{DISCUSSION}

In this study, establishing a methodological criterion aiming to measure the quality of the nutritional information about food recipes accessible on the Internet was a complex task, considering the existence of a growing volume of electronic addresses covering this theme.

The availability of a variety of platforms - such as site, blog, or site/blog - to convey recommendations to the lay public also complicates the collection of the data available in the virtual network ${ }^{6}$. Most of the pages submitted to the evaluations were classified as site. However, in the last five years the multifunctionality of the social network - by enabling simultaneous access to the social circle, to news, and even to health-related information, for example - has strengthened its popularization.

In addition, it is of great relevance that the source consulted be readable and comprehensible. The Department of Electronic Government of Brazil suggests that to be more readable, material should be organized in a simple manner, with correct writing and language familiar to the reader, formatted in light colors, and arranged in simplified layouts. This favors the understanding of what is read and prevents the user from diverting attention to the design of the letters or to the peculiarities of the column of text. ${ }^{8}$ In this regard, the URLs in this survey were adequate.

As far as author identification is concerned, it is essential that any information should indicate the person responsible; regardless of the medium in which it is published ${ }^{5}$. This allows the public to verify that the content designer is properly qualified in the subject area. Less than half of the addresses consulted satisfied this requirement, which implies an unsatisfactory result. It is emphasized that the identity of the author is indispensable even in the online portals under the responsibility of government institutions or organizations without commercial interests, a circumstance that the current observation confirms.

The Internet has prompted a series of transformations in the perspectives related to communication and the acquisition of knowledge in the health area. However, analysis of the quality of the disseminated information still presents limitations. ${ }^{3,4,5}$ The instruments made for this purpose are scarce; those available are presented exclusively in English and need re-assessments and re-adaptations, since technological changes have impacts on changes in the web environment itself ${ }^{5,6}$.

In 2001, the United States Agency for Healthcare Research and Quality (AHRQ) issued the document "Criteria for Assessing the Quality of Health Information on the Internet", which included some precepts for measuring the quality of health information posted on the virtual network ${ }^{16}$

Subsequently, in 2005, the European Commission announced the declaration, "Recommendations to promote Health Literacy by the means of the Internet", in order to clarify the national and regional authorities of the Member States, as well as the institutions and councils of health professionals, with regard to the publication of online content that met the quality requirements ${ }^{17}$.

It must be mentioned that the Swiss-based Health
On the Net Foundation (HON) grants a certification seal to pages that are in accordance with the principles of its code of conduct $^{18}$. Many consider it a standard of reference for health information accreditation. URLs that contain the HON seal are monitored annually and readers have access to instrumental videos that assist them in identifying trusted references.

In Brazil, only one official initiative was verified from this point of view. In 2001, the Regional Medical Council of São Paulo (CREMESP) produced the "Ethics Guide for Medical and Health Websites on the Internet"19. Consequently, it began to demand that its registered professionals and health institutions comply with the standards indicated for idealization, registration maintenance, and professional practice on pages or virtual portals about medicine and health.

The literature records a limited number of scientific publications that aim to study the reliability of Brazilian pages. Also, no studies were found that dealt specifically with electronic media containing recommendations for snacks described as healthy and indicated for preschoolers, which limited the discussion. For this reason, our results were compared with several studies that addressed the topic of food intake in childhood.

It is emphasized that a healthy routine since childhood - with a balanced diet and physical activity - is naturally understood as protective. The intake of an unbalanced diet can interfere in terms of weight gain and result in obesity ${ }^{1,2}$.

Studies indicate that the dietary consumption of Brazilian children needs more attention. The human right to food is provided for in the Brazilian Constitution, and the National Food and Nutrition Policy has made the promotion of adequate feeding a guideline, aimed at restoring quality of life and reducing health problems $\mathrm{s}^{20,21}$.

Alves et $a .^{22}$, upon analyzing the weekly food intake of preschoolers evaluated in the National Demographic and Health Survey of 2006, found an insufficient consumption of leafy vegetables and legumes. In contrast, a frequent intake of unhealthy preparations such as fried foods, sweets, soft drinks, and artificial juices was observed.

Leal et $a l .^{23}$ obtained similar results in a random sample of children living in Pelotas (RS). Only $45.7 \%$ of the participants met the recommendation advocated by the Healthy Eating Index for vegetables and legumes; 100\% were excessively consuming foods belonging to the oils and fats category; $99.6 \%$ were consuming more than one serving of food from the sugars, candies, chocolates, and salty snacks group.

In light of this, our findings are alarming, since only $31.4 \%$ of the total pre-evaluated cooking recipes followed steps 6, 7, and 8 of the Food Guide. It is astounding to encounter recommendations called healthy, but that have not even met the basic nutritional recommendations, especially since they are targeted at a biologically more vulnerable age group.

Insufficient consumption of vegetables and legumes compromises micronutrient and fiber intake. The latter promotes satiation, promotes intestinal trophism, and its chewing prevents the formation of bacterial plaques and cavities ${ }^{22,23}$ 
The frequent consumption of soft drinks, artificial juices, and other sugary drinks is associated with a decrease in the intake of natural juices and caloric increase in the diet, contributing to weight gain and its consequences. ${ }^{1}$ In the same sense, the frequent consumption of fried foods, sweets, and cookies, produces an increase in the energy density of the meals ${ }^{23}$.

Regarding the calcium and iron inadequacies in the recipes studied: calcium constitutes a fundamental substrate for the transmission of nerve impulses, muscular contraction, blood coagulation, and secretion of hormones; Its deficiency is directly related to shortness of stature and bone diseases ${ }^{24}$; lack of iron may be reflected in iron deficiency anemia, which in turn causes serious damage to children's cognitive and motor development, thus compromising school performance ${ }^{25}$.

Thus, it is relevant that researchers and health professionals are engaged in promoting healthy eating, especially in childhood, because this is a phase in which eating behavior is built, encouraging the acquisition of proper habits that can be long lasting. The nutritionist's actions as the expert responsible for assisting in formulating information directed to the lay public will minimize inaccuracies. The media should be utilized to promote the transmission of knowledge, however, in an appropriate way ${ }^{4}$.

The present research offers these advantages: in the approach to the credibility of health information available on the virtual network, studies with Brazilian web pages are scarce; moreover, we were pioneers for having investigated the nutritional quality of snacks recommended for preschoolers on the Internet. Nevertheless, some limitations should be considered: first, we did not apply a validated questionnaire to analyze the quality of health information, such as the Discern Questionnaire, which would certainly have enabled us to provide further clarification $^{26,27}$; second, given the daily increase in the number of Internet pages and, as pointed out by Giglio et $a l .{ }^{6}$, in view of the current Google ${ }^{\circledR}$ search engines, the public may have access to distinct results, but we believe that several of the 20 electronic addresses included in this study are also located by most users.

In conclusion, it is observed that less than half of the pages consulted identified the author. In addition, the recipes were predominantly misleading: only $31.4 \%$ fulfilled steps 6, 7, and 8 of the Food Guide; in the qualitative analysis, the majority presented inadequacies regarding macronutrient and micronutrient content.

\section{REFERENCES}

1. World Health Organization (WHO). Report of the commission on ending childhood obesity. Geneva: WHO; 2016.

2. Lobstein T, Jackson-Leach R, Moodie ML, Hall KD, Gortmaker SL, Swinburn BA, et al. Child and adolescent obesity: part of a bigger picture. Lancet. 2015;385(9986):2510-20. DOI: http://dx.doi.org/10.1016/ S0140-6736(14)61746-3

3. Silva RQ, Gubert MB. Qualidade das informações sobre aleitamento materno e alimentação complementar em sites brasileiros de profissionais de saúde disponíveis na internet. Rev Bras Saúde Matern Infant. 2010;10(3):331-340. DOI: http://dx.doi.org/10.1590/S1519-38292010000300006

4. Eysenbach G, Powell J, Kuss O, Sa ER. Empirical studies assessing the quality of health information for consumers on the World Wide Web: a systematic review. JAMA. 2002; 287(20):2691-700. DOI: http:// dx.doi.org/10.1001/jama.287.20.2691

5. Malafaia G, Castro ALS, Rodrigues ASL. A qualidade das informações sobre doenças disponíveis em websites brasileiros: uma revisão. Arq Bras Ciên Saúde. 2011;36(2):72-8. DOI: http://dx.doi.org/10.7322/ abcs.v36i2.63

6. Giglio AD, Abdala B, Ogawa C, Amado D, Carter D, Gomieiro F, et al. Qualidade da informação da internet disponível para pacientes em páginas em português. Rev Assoc Med Bras. 2012;58(6):645-649. DOI: http://dx.doi.org/10.1590/S0104-42302012000600007

7. Moura MA. Cultura informacional e liderança comunitária: concepções e práticas. Belo Horizonte: UFMG/ PROEX; 2011; p.150.

8. Brasil. Ministério do Planejamento, Orçamento e Gestão. Secretaria de Logística e Tecnologia da Informação. Modelo de acessibilidade em governo eletrônico. Brasília: MP/ SLTI; 2014; p. 92.

9. Brasil. Ministério da Saúde. Organização Pan-Americana de Saúde. Dez passos para uma alimentação saudável. Guia alimentar para crianças menores de dois anos. Brasília: OMS; 2010.

10. Brasil. Resolução RDC n.359, de 23 de dezembro de 2003. A Diretoria Colegiada da ANVISA/MS aprova o regulamento técnico de porções de alimentos embalados para fins de rotulagem nutricional. Brasília: Diário Oficial da União; 2003.

11. Brasil. Resolução RDC n.360, de 23 de dezembro de 2003. A Diretoria Colegiada da ANVISA/MS aprova o regulamento técnico sobre rotulagem nutricional de alimentos embalados. Brasília: Diário Oficial da União; 2003.

12. Núcleo de Estudos e Pesquisas em Alimentação (NEPA). Tabela Brasileira de Composição de Alimentos (TACO). 4 ed. rev. e ampl. Campinas: UNICAMP; 2011.

13. Pinheiro ABV, Lacerda EMA, Benzecry EH, Gomes MCS, Costa VM. Tabela para Avaliação de Consumo Alimentar em Medidas Caseiras. 5ed. São Paulo: Atheneu; 2008. 
14. Institute of Medicine. Dietary reference intakes for energy, carbohydrate. Fiber, fat, fatty acids, cholesterol, protein, and amino acids. Washington: 2002/2005.

15. Brasil. Ministério da Saúde. Fundo Nacional de Desenvolvimento da Educação. Programa Nacional Alimentação Escolar. Referências nutricionais para o programa nacional de alimentação escolar. Brasília: MS; 2009.

16. Agency for Healthcare Research and Quality (AHRQ). Assessing the quality of internet health information. Rockville: AHRQ; 1999.

17. Euro Health Net. Health literacy and internet: recommendations to promote health literacy by the means of the internet. Euro Health Net; 2005.

18. Health On The Net Foundation. The HON Code of Conduct for medical and health Web sites (HONcode). [cited: 2015 Nov 25]. Available from: https://www.hon.ch/HONcode/Patients/Conduct.html

19. Conselho Regional de Medicina do Estado de São Paulo (CREMESP). Guia de ética para sites de medicina e saúde na internet. [cited: 2015 Nov 25]. Available from: http://www.cremesp.org.br/?siteAcao=Pub licacoes\&acao=detalhes_capitulos\&cod_capitulo=26.

20. Carvalho CA, Fonsêca PCA, Priore SE, Franceschini SCC, Novaes JF. Food consumption and nutritional adequacy in Brazilian children: a systematic review. Rev Paul Pediatr. 2015;33(2):211-21. DOI: http:// dx.doi.org/10.1016/S2359-3482(15)30053-1

21. Bueno MB, Fisberg RM, Maximino P, Rodrigues GP, Fisberg M. Nutritional risk among Brazilian children 2 to 6 years old: a multicenter study. Nutrition. 2013;29(2):405-10. DOI: http://dx.doi.org/10.1016/j. nut.2012.06.012

22. Alves MN, Muniz LC, Vieira MFA. Consumo alimentar entre crianças brasileiras de dois a cinco anos de idade: Pesquisa Nacional de Demografia e Saúde (PNDS), 2006. Cienc Saúde Coletiva. 2013;18(11):336977. DOI: http://dx.doi.org/10.1590/S1413-81232013001100026

23. Leal KK, Schneider BC, França GVA, Gigante DP, Santos I, Assunção MCF. Diet quality of preschool children aged 2 to 5 years living in the urban area of Pelotas, Brazil. Rev Paul Pediatr. 2015;33(3):310-17. DOI: http://dx.doi.org/10.1016/j.rpped.2015.05.002

24. Bueno AL, Czepielewski MA. The importance for growth of dietary intake of calcium and vitamin D. J Pediatr (Rio J). 2008;84(5):386-395. DOI: http://dx.doi.org/10.2223/JPED.1816

25. Castro TG, Silva-Nunes M, Conde WL, Muniz PT, Cardoso MA. Anemia and iron deficiency among schoolchildren in the Western Brazilian Amazon: prevalence and associated factors. Cad Saude Publica. 2011;27(1):131-42. DOI: http://dx.doi.org/10.1590/S0102-311X2011000100014

26. Charnock D, Shepperd S, Needham G, Gann R. DISCERN: an instrument for judging the quality of written consumer health information on treatment choices. J Epidemiol Community Health. 1999;53(2):105-11.

27. Discern Online. Quality criteria for consumer health information [cited: 201617 Fev. 17] Available from: http://www.discern.org.uk/.

This article is distributed under the terms of the Creative Commons Attribution 4.0 International License (http://creativecommons.org/licenses/by/4.0/), which permits unrestricted use, distribution, and reproduction in any medium, provided you give appropriate credit to the original author(s) and the source, provide a link to the Creative Commons license, and indicate if changes were made. The Creative Commons Public Domain Dedication waiver (http://creativecommons.org/publicdomain/zero/1.0/) applies to the data made available in this article, unless otherwise stated. 


\section{Resumo}

Introdução: Preocupações a respeito da alimentação adequada na infância têm recebido destaque pela mídia. Acompanha-se uma elevação recorrente do número de páginas da internet, inclusive em redes sociais, canalizadas à prestação de informações sobre saúde.

Objetivo: Analisar a qualidade nutricional de receitas culinárias para lanches apresentados em páginas da internet, direcionados aos pré-escolares e descritos como saudáveis.

Método: Estudo transversal efetuado em 2015. Foi realizada uma busca por páginas brasileiras dirigidas ao público leigo que continham lanches para crianças entre 2 a 6 anos de idade. Foram selecionados os 20 primeiros URL localizados pelo instrumento de busca e separada a quantia de $10 \%$ das receitas. Foi verificado se os lanches cumpriam os passos 6, 7 e 8 do Guia Alimentar. Posteriormente, foram confeccionados rótulos nutricionais das preparações que atendiam aos três passos pré-estabelecidos

Resultados: $85 \%$ das páginas eram sites, $5 \%$ eram blogs e as restantes foram apontadas como sites/ blogs. Constatou-se que todas eram legíveis/compreensíveis e $40 \%$ exibiam a identificação do autor. Das 35 preparações inicialmente observadas, $31,4 \%$ cumpriam os três passos para uma alimentação saudável. $\mathrm{Na}$ análise qualitativa, sete foram consideradas hipocalóricas; somente um dos lanches se aproximou do teor proposto para carboidrato; dois apresentavam excesso proteico. De forma geral, as receitas tinham baixas quantidades de: lipídeo, cálcio, ferro, sódio e fibra.

Conclusão: Menos da metade dos endereços consultados registrava o autor. Além disso, as receitas culinárias estavam predominantemente equivocadas, pois a maioria apresentava inadequações quanto aos teores de macronutrientes e de micronutrientes.

Palavras-chave: criança, hábitos alimentares, nutrição, internet. 